\title{
1. Introduction to the Research Handbook on Global Climate Constitutionalism
}

\author{
Jordi Jaria-Manzano and Susana Borràs
}

\section{ANTHROPOCENE NARRATIVE AND GLOBAL GOVERNANCE}

'Anthropocene' is a word describing a new geological era in which the dynamics of the Earth system, the very configuration of the planet, are mostly governed by human activity. This concept was proposed by Nobel Prize winner Paul J Crutzen in 2002, in a piece published in Nature. ${ }^{1}$ However, the term itself was coined by Eugene F Stoermer, who is said to have used it since the 1980s. ${ }^{2}$ In any event, the idea was not new, as Crutzen himself recognizes - he mentions Antonio Stopani as a precedent, who had written about the Anthropozoic Era as early as $1873 .^{3}$ The term 'Anthropocene' accurately captures the historical moment in which humanity as a whole is now living, having been embroiled in a global environmental crisis since the end of the last century. ${ }^{4}$ At this moment, it seems established against all other contenders as the most apposite concept to describe this experience. ${ }^{5}$

For this reason, the concept of the Anthropocene has been used over the last 15 years in different contexts to capture the mood of the times and to provide an adequate frame for global environmental law in the present. ${ }^{6}$ The existence of reasonable criticisms about some misunderstandings associated with the term does not negate the validity of the Anthropocene concept. It expresses the situation of humanity confronted with the global transformation of the biosphere through anthropic action, which ends in a situation of self-sufficiency of social

See Paul J. Crutzen, 'Geology of mankind' (2002) 415 Nature 23.

See Louis J. Kotzé, Global Environmental Constitutionalism in the Anthropocene (Hart, 2016) 32-33. Crutzen and Stroemer published a paper together which can be considered as the first publication where the notion is used in a formal way. See Paul J. Crutzen, Eugene F. Stoermer, "The "Anthropocene" (2000) 41 Global Change Newsletter 17.

3 Ibid. Vladimir Vernadsky introduced the analogue concept of noosphere in the first half of the twentieth century. See Jonathan D. Oldfield, Denis J.B. Shaw, 'V.I. Vernadsky and the noosphere concept: Russian understandings of society-nature interaction' (2006) 37 Geoforum 145.

4 The term 'Anthropocene' has still not been officially accepted by the geologist community, but the Anthropocene Work Group (AWG) presented the evidence at its disposal in the last International Geological Congress, held in Cape Town between 27 August and 4 September 2016. The AWG recommended the acceptance of the term provisionally. See 'Media note: Anthropocene Working Group (AWG)' (University of Leicester), www2.le.ac.uk/offices/press/press-releases/2016/august/media-note -anthropocene-working-group-awg. According to the evidence gathered by the group, 1950 would be the date of the beginning of this new geological era. About the AWG, see 'Working Group on the Anthropocene', https://quaternary.stratigraphy.org/workinggroups/anthropocene.

5 See Kotzé, Global Environmental Constitutionalism in the Anthropocene, above n 2, 38.

6 This is the main argument in Kotzé, above $\mathrm{n} 2$. 


\section{Research handbook on global climate constitutionalism}

reproduction. ${ }^{7}$ The idea of the Anthropocene has captured some sort of epochal mood in terms of awareness of the social construction of physical reality in a global context: ${ }^{8}$

[It] invites a holistic perspective on the globally interconnected and reciprocally related Earth system, Earth system changes and the connection between the Earth system, its changes and the increasingly globalised human social system and the impacts of humans on the Earth system. ${ }^{9}$

This narrative focuses on the self-sufficiency of social reproduction and colonization of nature, implying the possibility of destroying the biophysical base of social processes. ${ }^{10}$ This allows us to conceive of the idea of global catastrophe, which is essential to the social construction of the environmental crisis in the second half of the twentieth century. ${ }^{11}$ If during the Cold War the nuclear war was the main metaphor about this, introducing a new disaster narrative, during the 1990s climate change took over, becoming a key focus in global politics and contributing to frame the idea of Anthropocene since then. ${ }^{12}$ The effects of human activity on the climate represent the dimension of human transformation of the biosphere, as well as the need to channel human activity through political and legal institutions to avoid catastrophe. ${ }^{13}$ For this reason, climate politics are the point of convergence between the Anthropocene narrative and global constitutionalism - a growing topic of research among lawyers. ${ }^{14}$

The starting point of this book is to build a coherent argument looking at climate change from the point of view of global constitutionalism, which fits with the idea of the Anthropocene creating a global space of social reproduction. In our opinion, the implications of this in social and legal arguments are significant, because they suggest the need to think seriously about a global polity and then to start to think legally in another way. We see global constitutionalism as a conceptual basis to build strategies of global governance in an era when social reproduction has escalated to a global level and defines even its own physical environment. In this context, we perceive legal scholarship as devising 'the fundamental concepts and structures' and elucidating 'current law in light of general principles', but also inspiring and criticizing 'legal developments' in order to react to a new situation defined by the Anthropocene narrative. ${ }^{15}$

7 See Karin Mickelsen and William Rees, 'The Environment: Ecological and Ethical Dimensions' in Elaine L. Hughes, Alastair R. Lucas and William A. Tilleman II (eds), Environmental Law and Policy (Emond Montgomery, 1993) 3.

8 This is the perspective of social scientists such as Alberto Melucci, in The Playing Self. Person and Meaning in the Planetary Society (CUP, 1996).

$9 \quad$ See Kotzé, Global Environmental Constitutionalism in the Anthropocene, above n 2, 184.

10 See Marina Fischer-Kowalski and Helmut Haberl, 'Sustainable development: socio-economic metabolism and colonization of nature’ (1998) 158(4) International Social Science Journal 573.

11 See Charles Alexandre Kiss and Dinah Shelton, Manual of European Environmental Law (CUP, 1993) 10 .

12 See Thomas Lowe, Katrina Brown, Suraje Dessai, Miguel de França Doria, Kat Haynes and Katharine Vincent, 'Does tomorrow ever come? Disaster narrative and public perceptions of climate change’ (2006) 15(4) Public Understanding of Science 435.

${ }_{13}$ The evidence on climate change and possible effects is available at www.ipcc.ch/publications_and _data/publications_and_data.shtml.

14 See Anne Peters, 'Global Constitutionalism' in Michael Gibbons (ed), The Encyclopedia of Political Thought (Wiley-Blackwell, 2015).

15 See Armin von Bogdandy, 'Comparative Constitutional Law: A Contested Domain. A Comparative Constitutional Law: A Continental Perspective' in Michel Rosenfeld and András Sajó (eds), The Oxford Handbook of Comparative Constitutional Law (OUP, 2012) 26-27. 
Hence, we see this narrative as creating a universal city, in which unique global community is confronting the traditional difference - at least in Western thought - between 'physis' and 'polis', thus requiring a constitutional framing. ${ }^{16}$ It is necessary to complement the crisis of sustainability, which is implied in the Anthropocene narrative, with the crisis of justice which is created in the emerging global community. Some critics have pointed out that the Anthropocene hides the structural differences in terms of the use of fossil fuels and consequently, in terms of responsibility for the effect of that, that is, climate change. ${ }^{17}$ This leads us to consider that any constitutional framework reacting to the Anthropocene should start from environmental justice, defined in terms of a fair distribution of the burdens and benefits of a global social metabolism (distributive justice), and respect for the plurality of forms of social reproduction (justice of recognition). ${ }^{18}$

Therefore, we assume the need to establish a constitutional framework as an anchoring point to define the legal semantics of any significant social reaction to the implications of the Anthropocene. ${ }^{19}$ This framework should be conceived in terms of sustainability - that is, how a global community should act in defining its own physical environment, to protect this in order to survive..$^{20}$ Moreover, in terms of justice, given the important differences in distribution of the burdens and benefits in the social use of the biosphere, these differences are also important in terms of participation in decisions that affect such use. ${ }^{21}$ In our opinion, the most significant area where the Anthropocene narrative manifests itself, and where these issues about justice and sustainability are clearest, is climate change. ${ }^{22}$ This is why we have chosen this topic and why we think that a constitutional approach makes sense here.

\section{AN OPEN CONSTITUTIONAL CONCEPT FOR THE ANTHROPOCENE}

This book is intended to be a research overview, linking climate change governance with global constitutionalism in a context where humans are modifying the climate system and

16 On the traditional distinction in Greek thought between nomos and physis, see W.K.C. Guthrie, The Sophists (CUP, 1971) 55ff.

17 See Andreas Malm and Alf Hornborg, 'The geology of mankind? A critique of the Anthropocene narrative' (2014) 1(1) The Anthropocene Review 62.

18 See Jordi Jaria-Manzano, ‘Environmental Justice, Social Change and Pluralism' (2012) IUCN Academy of Environmental Law e-Journal 18. Environmental justice has evolved as this comprehensive idea from a more limited conception in its origins in the United States, where it focused on the environmental impact suffered by poor and non-white communities compared with wealthy and white ones, particularly related to pollution. On this original vision of environmental justice, see Adam S. Weinberg, 'The Environmental Justice Debate: A Commentary on Methodological Issues and Practical Concerns' (1998) 13(1) Sociological Forum 25.

19 See Peer Zumbasen, 'Carving our typologies and Accounting for differences across Systems: towards a methodology of transnational constitutionalism' in Rosenfeld and Sajó, above n 15, 96 (2012).

20 Sustainability should be interpreted in a broader perspective than sustainable development. See Klaus Bosselmann, The Principle of Sustainability. Transforming Law and Governance (Ashgate, 2008).

21 See Ruchi Anand, International Environmental Justice (Ashgate, 2004) 139.

22 See Jesse Ribot, 'Cause and Response: Climate Vulnerability in the Anthropocene' (2014) 41(5) Journal of Peasant Studies 667. 


\section{Research handbook on global climate constitutionalism}

where a political response - that is, a constitutional framework - is needed..$^{23}$ Climate change is seen here through the lens of the Anthropocene narrative - as a description of the reach of anthropic transformation in the physical basis of social reproduction - and consequently, as a global challenge which cannot be escaped. ${ }^{24}$ As this requires governance of the Earth system, global constitutionalism seems to be an adequate approach. ${ }^{25}$ We will focus on defining the substance of global constitutionalism, trying to identify core content that guides governance, not to provide institutional solutions. We see the constitution as an open regulatory field where social conflicts find (provisional) solutions and governance is effected, 'breaking down the complementary association between the state and the constitution' ${ }^{26}$

The constitution is therefore a social construct, in which norms and practices are built and modified according to decisions of institutional actors, but also through the legal culture, where academics can envisage new approaches and encourage new strategies. Considering the challenges that the Anthropocene presents regarding sustainability and justice, it seems necessary to work on the construction of fundamental constitutional ideas which can inspire institutions, promote spaces of self-determination for communities and facilitate the control of power through the courts. We see constitutionalism as 'law's unveiling of its emancipatory potential' ${ }^{27}$

As far as '[1] egal scholarship develops and often even devises the fundamental concepts and structures, elucidates and legitimates the current law in light of general principles [and] inspires and criticizes legal developments', ${ }^{28}$ we see our research as an attempt to build a functional concept of constitution adapted to the needs of humanity in the Anthropocene, based on a reconstruction of current legal conceptions within a new framework of interpretation. Starting from this, we will consider global constitutionalism on the basis of the need of substantive contents, aimed at intragenerational and intergenerational justice, as a framework of global governance in the transition to the Anthropocene.

The constitution was conceived differently in the European and American traditions after the revolutions at the end of the eighteenth century. In Europe, the concept of the codification of political institutions was pre-eminent with regard to the idea of substantial limitations of political power - a concept that was crucial in the American tradition..$^{29}$ A strong understanding of the constitution as a contract has significant implications, as it points to the consequence

23 See the evidence about this in Intergovernmental Panel on Climate Change, Climate Change 2014. Synthesis Report (2014) 40ff.

${ }^{24}$ See Jutta Brunnée, 'Climate Change, global environmental justice and international environmental law' in Jonas Ebbeson and Phoebe Okowa (eds), Environmental Law and Justice in Context (CUP, 2009) 316.

25 See Sam Adelman, 'Rethinking human rights: the impact of climate change on the dominant discourse' in Stephen Humphreys (ed), Human Rights and Climate Change (CUP, 2010) 174.

26 See Zumbasen, above n 19, 96.

27 Ibid.

28 Vid Von Bogdandy, above n 15, 26-27.

${ }_{29}$ In fact, institutionalism almost excludes the fundamental rights of the academic approach to constitutional law. See, for example, Pietro Virga, Diritto costituzionale (9th edn, Giuffrè, 1979) 4. This is caused by the weight of the idea of law as an outcome of the will of political power, shown in the traditional principle quod principi placuit legis habet vigorem. See Walter F. Murphy, 'Civil Law, Common Law and Constitutional Democracy' (1991) 52(1) Louisiana Law Review 91, 94. With this concept, the rights are a mere form, not a substance, exposed to the will of the legislatures. See Gustavo Zagrebelsky, El derecho dúctil. Ley, derechos, justicia (Marina Gascón tr, Trotta, 1995) 48. 
that not whatever constitutional code should be considered as legitimate, but only that guaranteeing certain contents related to the protection of the people signing the original social contract. ${ }^{30}$ The link between constitution, control of power and recognition of a certain status of the members of the polity deploys itself into a material conception of constitution, which allows legal positivism to be overcome. ${ }^{31}$ This gives way to a concept of constitutional law which is less formal and more open; which allows for the definition of strategies of control of institutions and decisions when they affect the status of members of the community.

This is why, focusing on a climate constitution, we begin by considering this substantial status of the constitution as a basis for developing a normative structure which defines the limits and values of climate governance in the context of the Anthropocene narrative. The original social compact is 'the supreme Law of the Land'. ${ }^{32}$ Therefore, it can be used as a parameter to control power, as well as to define the fundamental status of members of the community. Conceiving 'constitution' in this way - more as substantial norms organizing social exchange than defining an institutional apparatus - we can advance in terms of developing the ideas of global constitutionalism regarding climate change.

Our idea in this book is to explore a conception of the constitution conceived as an axiological core of a certain society, as a point of reference for the fundamental values of a community ${ }^{33}$ - here, in the framework of the Anthropocene narrative, the global community. This substantial idea of constitution is intimately related to its use by the courts as a set of legal norms to control power. ${ }^{34}$ Accordingly, we must explore how a certain set of norms can define substantial limits for climate change politics and can be used by the courts to control the outcome of decision-making processes, in a global context, with different actors affecting

30 This is clear in Article XVI of the Declaration of Rights of Man and the Citizen: 'Toute société dans laquelle la garantie des droits n'est pas assurée ni la séparation des pouvoirs déterminée, n'a point de Constitution.' This is a key document in the history of constitutionalism, despite the fact its implications were not fully developed in the continental tradition until the end of the Second World War. It is true that important constitutional lawyers in French history, such as Carré de Malberg, Adhémar Esmein, Léon Duguit and Maurice Hauriou, had defended the judicial review, but with little success until the Constitution of 1959. See Jacques Chevallier, 'L'État de droit' (1998) 2 Revue de Droit Public 313, 333-334.

31 See Pedro Cruz Villalón, 'Formación y evolución de los derechos fundamentales (1988)' in La curiosidad del jurista persa y otros estudios sobre la Constitución (2nd edn, Centro de Estudios Políticos y Constitucionales, 2006) 189.

32 See Article VI of the Constitution of the United States of America.

33 See Ulrich Häfelin and Walter Haller, Schweizerisches Bundesstaatsrecht (5th edn, Schultess, 2001) 8-9.

34 As is underlined in Marbury $v$ Madison, 5 US 137 (1803), 'all those who have framed written constitutions contemplate them as forming the fundamental and paramount law of the nation, and consequently, the theory of every such government must be, that an act of the legislature, repugnant to the constitution, is void'. The idea of the constitution as an original social compact allowing control of power can be traced in The Federalist Papers, particularly in Chapter 48, authored by James Madison. Subsequently, Andrew Hamilton can say in Chapter 78:

By a limited Constitution, I understand one which contains certain specified exceptions to the legislative authority; such, for instance, as that it shall pass no bills of attainder, no ex-post-facto laws, and the like. Limitations of this kind can be preserved in practice no other way than through the medium of courts of justice, whose duty it must be to declare all acts contrary to the manifest tenor of the Constitution void. Without this, all the reservations of particular rights or privileges would amount to nothing.

Available at http://avalon.law.yale.edu/18th_century/fed78.asp. 


\section{Research handbook on global climate constitutionalism}

how human action is transforming climate. A substantive idea of rule of law is thus aligned with governance innovation associated with the transition to the Anthropocene. In short, we are thinking of a constitution embedded in its time, a 'Verfassung in der Zeit' . ${ }^{35}$

We favour a substantial conception of the constitution more than a formal one - a complex of fundamental norms building the core of legitimacy in any community, providing tools for control of power and guaranteeing the status of members of that community. ${ }^{36}$ For this reason, we consider the constitution as a normative apparatus for organizing the fundamentals of political and social life in a community and providing a framework for decision-making processes. ${ }^{37}$ The fundamental decisions should not necessarily be taken in the formal constitution and, in fact, there is no need for a formal constitution at all. ${ }^{38}$ Moreover, a formal constitution can include Akzidentalien (ie, non-fundamental contents), and can lack Essentialien (ie, fundamental contents). ${ }^{39}$ In this sense, we can create a constitution for any community, even the global community in the Anthropocene.

The substantial constitution envisaged here consists of a complex framework and defining processes, and contains material content which can be used by the courts in order to review the correctness and legitimacy of decisions in a given political community. ${ }^{40}$ Beyond that function, constitutional norms should have dense political content, allowing the community to identify with them, giving coherence and cohesion to the political system. ${ }^{41}$ In any case, we do not conceive of constitution in a narrow sense, but rather see it as 'entrenched in several different legal and non-legal ways (and not only through a formal, super-majoritarian amendment process) and enforced by various techniques of constitutional review (and not only a formal judicial invalidation power)' ${ }^{42}$ Accordingly, 'big-C constitutional law will be one important type of constitutional law but not the exclusive one'. ${ }^{43}$

35 See Konrad Hesse, 'Verfassung und Verfassungsrecht' in Ernst Benda, Werner Maihofer and Hans-Jochen Vogel, Handbuch des Verfassungsrechts (2nd edn, De Gruyter, 1994) 11.

36 The distinction between formal and material constitution has been a classic topic in continental law, as shown in Jean-François Aubert, 'Notion et fonctions de la Constitution' in Daniel Thürer, Jean-François Aubert, Jörg Paul Müller (eds), Verfassungsrecht der Schweiz / Droit constitutionnel Suisse (Schulthess, 2001) 5; Andreas Auer, Giorgio Maliverni and Michel Hottelier, Droit constitutionnel Suisse. I. L'Etat (Stämpfli, 2000) 8; and Riccardo Guastini, 'Sobre el concepto de Constitución' in Miguel Carbonell (ed), Teoría de la Constitución. Ensayos escogidos (Porrúa. 2005) 97. The distinction used here is different from that used by Constatino Mortati in his classic work La costituzione in senso materiale, where material constitution is understood as a fact more than as a normative complex. This second meaning of material constitution has been very influential in Italian scholarship. See, for example, Paolo Barile, Istituzioni di diritto pubblico (6th edn, Cedam, 1991) 9; and Donato Donati, 'Costituzione' in Scritti di diritto pubblico (II) (Cedam, 1966) 405ff. For a distinction between both meanings of material constitution in civil law systems, see Gustavo Vignocchi and Giulio Ghetti, Corso di diritto pubblico (4th edn, Giuffrè, 1991) 25-26.

37 See Thomas Dunn, Die richtige Verfassung (Schulthess, 1971) 11.

38 See Jean-François Aubert, Traité de droit constitutionnel Suisse (Ides et Calendes, 1967) 101.

39 See Dunn, above n. 37, 13.

40 See Walther Burckhardt, Die Organisation der Rechtsgemeinschaft. Untersuchungen über die Eigenart des Privatrechts, des Staatsrechts und des Völkerrechts (2nd edn, Schulthess. 1944) 130.

${ }_{41}$ This has been underlined particularly by Peter Häberle, for example, in 'Die Verfassung «im Kontext»', in Thürer, Aubert, Müller, above n 36, 19, where he speaks of the constitution as a 'Mittel der Kulturellen Selbstdarstellung des Volkes' - a medium for the cultural self-representation of the people.

${ }_{42}$ See Stephen Gardbaum, 'The place of constitutional law in the legal system' in Rosenfeld and Sajó, above n 15, 173.

43 Ibid. 
The constitution in this view is an 'anchoring point and reference perspective for the collision of existing and emerging legal semantics of society's self-governance', detached from the narrow conception of a public law text 'emanating from state authority and sitting at the pinnacle of a pyramid of legal normativity'. ${ }^{44}$ In our view, in order to use constitutional tools to react against the backdrop of the transition to the Anthropocene, some open concept of constitution is required, particularly disassociated from the state, given the need to build global instruments of governance that transcend the national law. In whichever case, we are referring to a legal conception of constitution which is a normative context, may be fluent and open, but is juridical - not a mere description of political fluxes, but a channel for them. ${ }^{45}$

Hence, the constitution is conceived here as the core of a changing social consensus, contained in different norms, and aimed at building a legal framework for global governance. This idea is particularly receptive to concepts from other disciplines that aim to define, expand and evolve social consensus, being a legal discourse in the frontier pervading all legal branches. ${ }^{46}$ This is why the connection between the Anthropocene narrative and the constitutional discourse seems so natural; and why scholarship is so important, as the construction of a constitutional discourse is required which transcends the traditional space of local constitutionalism to reach a global, pluralistic and complex dimension. ${ }^{47}$

This book starts from the assumption that global governance, in the context of the human species determining the configuration of the Earth system, needs to build a new consensus in a constitutional way. This is intended to reinforce social acceptance of decision making in its axiological foundations (legitimacy), as well as in processes and institutions, defining an accepted status for human members of global polity, as well as a sustainable definition of its interaction with the environment, with nature as a whole. ${ }^{48}$ For this reason, the constitutional discourse, even while taking into account national formal constitutions, is not limited to them. ${ }^{49}$ A human rights approach shows how a constitutional discourse can transcend national borders and help to facilitate the building of a new consensus. ${ }^{50}$ This provides a new base for decision-making processes in a global and complex society, but also tools to control them, with the ultimate idea that the constitution is a source of social cohesion, to the extent that it can guarantee limited government and the protection of the fundamental values of a society.

We have assumed that the Anthropocene narrative drives humanity to a global polity, which is organized in a very pluralistic and complex fashion, with many institutional (and non-institutional) actors, as well as multiple sources of law. In this context, it seems impossible to rely on a monistic idea of constitution, derived from the original decision of a certain

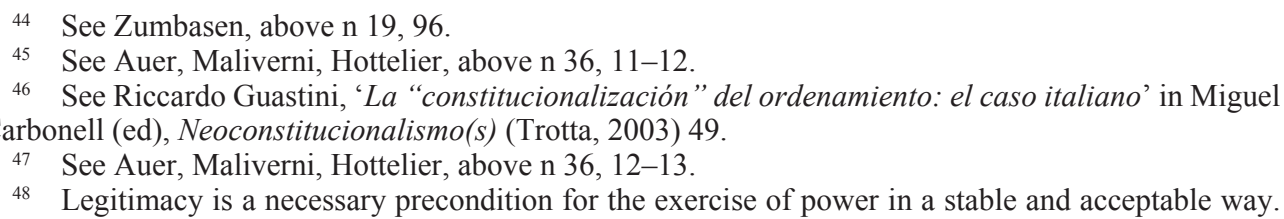
See Juan José González Encinar, 'La Constitución y su reforma' (1986) 17 Revista Española de Derecho Constitucional 345, 355; and Ralph Alexander Lorz, 'The Emergence of European Constitutional Law' in Eibe Riedel and Rüdiger Wolfrum (eds), Recent Trends in German and European Constitutional Law (Springer, 2006) 47.

49 See Miguel Herrero de Miñón, El valor de la Constitución (Crítica, 2003) 53.

50 The complex relationship between environmental protection and human rights in the international arena has been analysed in Alan Boyle's 'Human Rights and the Environment: Where Next?' (2012) 23 (3) European Journal of International Law 613. 
pouvoir constituent; rather, the existence of different norms of constitutional density and vocation at an international, supranational, national and local level should be considered. Therefore, we need to consider the construction of a sort of in-the-making constitutional system, comprised of different norms and built through political discussion, academic debate and judicial dialogue, which should be elaborated in whatever concrete case to provide a framework to take a certain decision. ${ }^{51} \mathrm{We}$ are not talking about a monistic universe defined by a single constitution, but rather 'a normative pluriverse, pushing towards comparison'. ${ }^{52}$ This is more a space of exchange, conflict and provisional consensus than the universe of a complete and structured juridical world order.

Therefore, we conceive of constitution and constitutionalism as the provisional consolidation of a complex and fragmented system of norms of different origin and relevance, according with a material concept. Hence, the constitution provides a concrete solution in a certain moment, opening the debate for the future; not pretending to be an expression of a monadic and monolithic legal system, defined through a formal constitution, but rather a provisional normative aggregation solving a conflict in a kaleidoscopic legal universe. We are not trying to define an organized legal system and self-referential political community, even at a global level, but rather a complex and changing normative reality dealing with global governance in a framework defined by the Anthropocene narrative. ${ }^{53}$

Starting from this concept, it is necessary to build a discourse expressing a provisional consensus which is defined within the framework of a constitutional culture of global dimension, open to a pluralist dialogue and to continuous evolution, where evidence - present in different texts - lives in permanent evolution and interaction. ${ }^{54} \mathrm{We}$ are confronting a complex reality of constitutional texts, defined through social recognition and legal argumentation, which acquire their sense in a dynamic way. ${ }^{55}$ Legal hermeneutics, in this context, should unite technical rigour with methodological eclecticism, defining an evolving set of texts, in order to offer the best solution to a conflict against the backdrop of a constitutional approach, where the act of interpretation is central. ${ }^{56}$ The judicial praxis in this conception is aimed at developing complex arguments in order to find a correct assignation in each case, where different normative materials are selected, ordered and interpreted beyond mere subsumption under general rules or precedents. ${ }^{57}$

From here on, law is conceived as an evolving dialogue among different interpreters - not only judges, but also other legal professionals, the parliament and executive, and even citizens and civil society organizations - finding provisional solutions for social conflicts in a constitutional way, integrating a global perspective according with the Anthropocene narrative. In

1 See Zagrebelsky, El derecho dúctil. Ley, derechos, justicia, above n 29, $114 \mathrm{ff}$.

2 See Von Bogdandy, above n 15, 26.

53 See Auer, Maliverni, Hottelier, above n 36, 9.

54 See Fulco Lanchester, 'Los constitucionalistas italianos entre el Estado nacional y la Unión Europea' in Francisco Balaguer Callejón (ed), Derecho constitucional y cultura. Estudios en homenaje a Peter Häberle (Tecnos, 2004) 79.

${ }_{55}$ The text is defining the space for legal interpretation, as pointed out by Raúl Canosa Usera in Interpretación constitucional y fórmula politica (Centro de Estudios Constitucionales, 1988) 95.

${ }_{56}$ See Juan José Moreso, 'Conflictos entre principios constitucionales' in Carbonell, above n 46, 100-101.

57 See Juan Antonio García Amado, 'El juicio de ponderación y sus partes. Una crítica' in Robert Alexy, Derechos sociales y ponderación (Fundación Coloquio Jurídico Europeo, 2007) 270-271. 
this dialogue, each participant is trying to build a general discourse, not to take a particular position, and to convince the others that its interpretation is the most correct, answering the question 'How do we want to live?', not 'How do I want to live?' ${ }^{58}$ This is why law is different from morals and is open to the possibility of dialogue, in a pluralist perspective, which is strongly linked to the idea of justice as recognition. ${ }^{59}$

This idea of constitution as a construct which is deployed in a concrete case by judges, taking into account the social dialogue about its contents, relies heavily on the role of the judiciary. Here it should be recognized that judges do not always reason and decide rationally.$^{60}$ However, judicial decisions are a key aspect in the control of power, guaranteeing counter-hegemonic positions in the governance of the Anthropocene and putting limits on corporations and public powers implying an aggressive use of resources. Moreover, this also implies a relativization of legal certainty, a construct based on a Laplacian conception of the world which is untenable within the framework of the Anthropocene narrative. ${ }^{61}$

We are aware of the problems that this conception can present regarding the traditional division of powers, and particularly regarding respect for the will of democratic legislatures. ${ }^{62}$ However, on the one hand, democratic legislatures are not always so democratic, because of the process of capture to which they are vulnerable in a global capitalist economy. ${ }^{63}$ On the other hand, the complexity of legal sources in the contemporary world cannot be reduced to the law passed by a particular parliament. In this context, the importance of legal interpretation seems obvious and the need to channel it through constitutional arguments also seems necessary. In short, we are proposing to advance to a constitutional system defined in a dynamic way through interpretation and reasoning, beyond the limits and restrictions implied by legal positivism, to create a core of social consensus that can provide tools to control power and governing complexity. Climate change seems to be a particularly interesting scenario in which to develop this kind of constitutional approach.

\section{THE COMPLEXITY OF CLIMATE GOVERNANCE}

The importance of climate change in the global debate is becoming more apparent through the scientific evidence collected, being considered as a 'common concern of humanity' in international law. ${ }^{64}$ Climate change is a particular point of confluence between the Anthropocene narrative and the challenges of governance in a global community, as the political and legal response over the last 25 years has shown. From the signing of the United Nations Framework

58 See Robert Alexy, 'Los derechos fundamentales en el Estado constitucional democrático' in Carbonell, above n $46,40$.

59 See Paolo Comanducci, 'Formas de (neo)constitucionalismo: un análisis metateórico' in Carbonell, above n $46,87$.

60 See op cit, 92.

${ }_{61}$ See Luis López Guerra, 'Algunas notas sobre el desarrollo de la doctrina constitucionalista española' (2010) 41 Revista Catalana de Dret Públic 85, 111.

62 See op cit, 112.

63 On the concept of regulatory capture, see Ernesto Dal Bó, 'Regulatory Capture: A Review' (2006) 22 Oxford Review of Economic Policy 203.

64 See Boyle, above n 50, 618. 
Convention on Climate Change (UNFCCC) ${ }^{65}$ in 1992 to the resulting Paris Agreement of the 21 th Conference of the Parties (COP) of Paris, adopted on 12 November 2015, ${ }^{66}$ it has been a long road of political awareness and debate, as well as legal reaction, providing the foundations for a constitutionalization of climate governance, which is the subject of this book.

A necessary implication of humanity's common concern regarding climate change is that States have a duty to cooperate to ensure that the climate and biological diversity are protected for the benefit of present and future generations. ${ }^{67}$ From this perspective, the common interest of humankind becomes the common heritage of humankind. This implies a common understanding by States to protect the atmosphere as trustees or custodians with duties to present and future generations. ${ }^{68}$ Far from the theory, as we will see in this book, the reality of the international climate change regime has been built without considering three main elements which are important in terms of a climate constitution and climate governance: fairness/equity, rights and responsibilities. After all the years of climate talks, climate governance has acted directly against climate justice goals: the failure of governments to take meaningful, urgent and coordinated policy action to address climate change has been the prevailing trend, together with the promotion of neoliberal and market logic as the only tools for solving the climate crisis.

Justice is at the heart of the international climate regime because anthropogenic climate change principally involves the rich imposing risks, costs and damages on the poor. The concept of climate justice imposes shared benefits and burdens equitably on least developed countries, in proportion to their past or present responsibility for the deterioration of the atmosphere, ${ }^{69}$ and claims for the respect and protection of human rights. Moreover, it ensures that decisions on climate change are participatory, transparent and accountable; highlight gender equality and equity; take advantage of the transforming power of education; and promote effective partnerships to ensure climate justice. $^{70}$

65 United Nations Framework Convention on Climate Change, 29 May, 1992, available at http:// unfccc.int/files/essential_background/background_publications_htmlpdf/application/pdf/conveng.pdf.

66 See the Paris Agreement, adopted by 21st Conference of the Parties in 2015, available at http:// unfccc.int/resource/docs/2015/ cop21/eng/10a01.pdf, and the Progress tracker of the work programme resulting from the relevant requests contained in decision 1/CP.21, available at http://unfccc.int/files/ paris_agreement/application/pdf/progress_tracker_26102016_1000.pdf. See Nicholas Chan, 'Climate Contributions and the Paris Agreement: Fairness and Equity in a Bottom-Up Architecture' (2016) 30(3) Ethics \& International Affairs 291.

${ }^{67}$ See A. C. Trindade and D. J. Attard, 'Report of the Proceedings of the Meeting' in D. J. Attard (ed), The Meeting of the Group of Legal Experts to Examine the Concept of the Common Concern of Mankind in Relation to Global Environmental Issues (1990) 24; and the Report of the Expert Group Meeting on Identification of Principles of International Law for Sustainable Development, Geneva, Switzerland, 26-28 September 1995, prepared by the Division for Sustainable Development for the Commission on Sustainable Development Fourth session, para 88, available at https://digitallibrary.un .org/record/212979/.

68 See Experts Group on Environmental Law of the World Commission on Environment and Development, Environmental Protection and Sustainable Development Legal Principles and Recommendations (1986) 42, art 2; and Edith Brown Weiss, In Fairness To Future Generations: International Law, Common Patrimony, and Intergenerational Equity (United Nations University, 1989) 86.

${ }^{69}$ See Steve Vanderheiden, Atmospheric Justice. A Political Theory of Climate Change (Oxford University Press, 2008).

70 See the Principles of Climate Justice (Mary Robinson Foundation), available at www.mrfcj.org/ principles-of-climate-justice/. 
Climate justice concerns are rooted in the immense differences in countries' historical and projected contributions to global greenhouse gas emissions, their vulnerability to climate change and their ability to bear the costs of mitigating or adapting to climate change. ${ }^{71}$ The asymmetrical relations are exacerbated by the fundamental difference in the balance of powers in the context of globalization, which is characterized by a persistent North-South divide, the predominance of powerful economic interests and the neutrality of a human rights and gender perspective. ${ }^{72}$ In fact, these different contributions and responsibilities have influenced the climate talks, in both the pre-2020 and post-2020 climate regimes, increasing the difficulties in reaching consistent agreements and balancing equity and fairness between deals and responsibilities.

In the pre-2020 period, when the negotiation process was first launched by the United Nations in 1990, all Conferences of Parties (COP) tried to face up to climate change, without losing competitiveness, while the impact of climate change was borne by the most vulnerable and poorest countries. Inequality and unfairness were revealed throughout the climate talks, in the lack of fair distribution of future and present responsibilities (distributive justice), a decision-making process (procedural justice) and compensation for past harm (compensatory justice) ${ }^{73}$ From the naïve optimism of Rio de Janeiro in 1992, when the UNFCCC was adopted, to the purposeful energy of Berlin (COP 1, 1995) and the dashed hopes of Kyoto (COP 3, 1997), the new Paris Agreement put more pressure on developing countries to assume emissions targets, ignoring the existence of a climate debt. ${ }^{74}$

The UNFCCC common goal focuses on the objective of stabilizing greenhouse gas concentration in the atmosphere at a level that would prevent dangerous anthropogenic interference with the climate system (Article 2). However, the Kyoto Protocol, although hailed as a political success, was not considered so successful by the scientific community. ${ }^{75}$ But at least it was a reasonable step in providing concrete emissions reduction targets for Annex I (developed) countries and formalizing the first practical and binding application of the UNFCCC with respect to non-Annex I (developing) countries.

Although it imposed overall emissions reductions of 5 per cent below 1990 levels ( 8 per cent for the EU) on 37 developed signatory countries over the period 2008-12, rich nations did very little under the Kyoto Protocol to reduce emissions by any meaningful amount. ${ }^{76}$ Significantly, the Kyoto Protocol regulated three market-based mechanisms as the means of meeting States' binding emissions reduction targets: emissions trading (carbon market), the Clean Development Mechanism and joint implementation. These mechanisms have been

71 See Darrel Moellendorf, 'Climate Change Justice' (2015) 10(3) Philosophy Compass 173.

72 See Chukwumerije Okereke and Philip Coventry, 'Climate justice and the international regime: before, during, and after Paris', (2016) 7 Wiley Interdisciplinary Reviews: Climate Change 834.

73 See Henry Shue, 'The Unavoidability of Justice' in Andrew Hurrell and Benedict Kingsbury (eds), The International Politics of the Environment: Actors, Interests, and Institutions (Clarendon Press, 1992) 373-397. See also from the same author 'Subsistence Emissions and Luxury Emissions' (1993) 15 (1) Law \& Policy 39.

74 Jonathan Pickering and Christian Barry, 'On the concept of climate debt: its moral and political value’ (2012) 15(5) Critical Review of International Social and Political Philosophy 667.

75 See the Kyoto Protocol to the United Nations Framework Convention on Climate Change, December 10, 1997, available at http://unfccc.int/resource/docs/convkp/kpeng.pdf.

76 See David G. Victor, The collapse of the Kyoto Protocol and the struggle to slow global warming (Princeton University Press, 2001). 
identified as a form of carbon market governance, a market-based form of climate governance. ${ }^{77}$ Hence, mistaken climate solutions architecture ${ }^{78}$ assigned an economic and financial value to the biosphere, to the ecosystems and in this case to a molecule of carbon dioxide, ${ }^{79}$ recognizing 'emissions rights' instead of 'human rights' ${ }^{80}$ The treaty was clearly inadequate in addressing the pressing issue of global warming and preventing the continued increase in global emissions: it took eight years to come into force and although most Kyoto Protocol signatories succeeded in cutting emissions, worldwide atmospheric carbon dioxide levels have soared by 35 per cent since 1997. Most of that increase has come from the same large developing countries that were not included in the Protocol. China and India, the world's largest emitters, and the United States, the biggest emitter through to the middle of the 2000 s, did not ratify the Protocol. For its part, Canada officially withdrew from the Protocol in 2012. ${ }^{81}$ Regardless, the Protocol was extended after the Doha Conference, ${ }^{82}$ setting a target to reduce overall greenhouse gas emissions in developed countries by at least 18 per cent between 2013-20 (the 'second commitment period'), compared to 1990 levels.

At its outset, the UNFCCC agreed on basic principles that govern the operation of negotiations. Two of these principles are historical responsibility for climate change and decision making by consensus (or lack of disagreement). These two principles were harshly attacked, especially during the Copenhagen climate talks (COP15) in December $2009 .{ }^{83}$ In the first place, responsibility for the generation of climate change lies with the so-called industrialized countries (eg, the US, EU, Canada, Australia), which represent approximately 25 per cent of the world's population, and which still have emissions per capita today far superior to those of any so-called emerging countries, such as China, India and Brazil. In any case, Copenhagen was the starting point for climate governance discussion on climate justice.

The 2010 Cancun Agreements, ${ }^{84}$ following the Resolutions of the Human Rights Council, offered for the very first time in UNFCCC negotiations an opportunity to ensure the adequate

77 See Frank Biermann, Philipp Pattberg and Fariborz Zelli, Global climate governance beyond 2012: architecture, agency and adaptation. (Cambridge University Press, 2010) 146-164.

78 See Amanda M. Rosen, 'The Wrong Solution at the Right Time: The Failure of the Kyoto Protocol on Climate Change' (2015) 43(1) Politics \& Policy 30.

79 See Andriana Vlachou, 'Climate Change: The Political Economy of Kyoto Flexible Mechanisms' (2010) 42 Review of Radical Political Economics 3249.

80 See Tim Hayward 'Human Rights Versus Emissions Rights: Climate Justice and the Equitable Distribution of Ecological Space' (2007) 21 Ethics \& International Affairs 431.

${ }^{81}$ United Nations, C.N.796.2011.TREATIES-1 (Depositary Notification), Canada: Withdrawal, 16 December 2011.

82 Conference of the Parties Serving as the Meeting of the Parties to the Kyoto Protocol, United Nations Framework Convention on Climate Change, Report of the Conference of the Parties Serving as the Meeting of the Parties to the Kyoto Protocol on Its Eighth Session, Held in Doha from 26 November to 8 December 2012, Addendum: Part Two: Action Taken by the Conference of the Parties Serving as the Meeting of the Parties to the Kyoto Protocol at Its Eighth Session, COP Dec 1/CMP.8, UN Doc FCCC/ KP/CMP/2012/13/Add.1 (28 February 2013) Annex I ('Doha Amendment to the Kyoto Protocol'). See Michael Bothe, 'Doha and Warsaw: Reflections on Climate Law and Policy' (2014) 4 Climate Law 5.

83 The Copenhagen Conference, 2009, resulted in a non-binding Copenhagen Accord, Decision 2/ CP.15, 'Copenhagen Accord', in FCCC/CP/2009/11/Add.1 (30 March 2010). See Lavanya Rajamani, 'The Making and Unmaking of the Copenhagen Accord' (2010) 59 International \& Comparative Law Quarterly 824.

${ }_{84}$ The Cancun Agreements, 2010, comprise Decision 1/CP.16, 'The Cancun Agreements: Outcome of the work of the Ad Hoc Working Group on Long-Term Cooperative Action under the Convention', 
fulfilment of human rights obligations under the Convention. ${ }^{85}$ There was an understanding that the impact of climate change is threatening the rights to life, food and culture, among other issues. In the aftermath of the Cancun climate conference, the parties to the UNFCCC took no specific action to address the link between human rights and climate change, overlooking 'those segments of the population that are already vulnerable owing to geography, gender, age, indigenous or minority status, or disability'. ${ }^{86}$

Since the 2012 United Nations Conference on Sustainable Development (UNCSD) ${ }^{87}$ certain frustrations have been evident with regard to the summits and international environmental agreements, which seem to be simply impracticable. This multilateral decline has occurred in the context of a world impacted by the threats posed by the new strategic security agenda following the events of 11 September 2001, and by the economic and financial crisis over the last half-decade. ${ }^{88}$ Envisaging a new post-2020 scenario, after COP19 in Warsaw, ${ }^{89}$ the bipolar, rigid and static types of commitments, based on the dichotomy between developing and developed countries, were replaced with a more flexible multilateral system of voluntary self-determined pledges. ${ }^{90}$

In the post-2020 negotiations, developing countries pushed for a continuation of the Kyoto system. During COP20 in Lima, ${ }^{91}$ unsuccessful attempts to respond to the multilateral self-determination obligations versus the achieving differentiated treatment were proposed by several countries, such as Brazil, which suggested progressive 'concentric differentiation';92

in FCCC/CP/2010/7/Add.1 (15 March 2011) [hereinafter 'Cancun Agreements LCA']; and, Decision 1/CMP.6, 'The Cancun Agreements: Outcome of the work of the Ad Hoc Working Group on Further Commitments for Annex I Parties under the Kyoto Protocol at its fifteenth session', in FCCC/KP/ CMP/2010/12/Add.1 (15 March 2011) [hereinafter 'Cancun Agreements KP']. See Lavanya Rajamani, 'The Cancun Climate Change Agreements: Reading the Text, Subtext and Tea Leaves' (2011) 60 International \& Comparative Law Quarterly 499.

85 See Alyssa Johl and Sébastien Duyck, 'Promoting Human Rights in the Future Climate Regime, Ethics' (2012) 15(3) Policy \& Environment 298; and Nicholas Stern, 'Ethics, Equity and the Economics of Climate Change' (Working Paper No 97, Centre for Climate Change Economics and Working Paper No 84, Policy and Grantham Research Institute on Climate Change, 2012).

${ }_{86}$ According to the Human Rights Council Resolution 10/4. Human rights and climate change, A/ $\mathrm{HRC} / \mathrm{RES} / 10 / 4,25 / 03 / 2009$, cited in the preamble of the Cancun Agreements.

87 Popularly known as Rio +20 , this was held from 13-22 June 2012 in Rio de Janeiro, Brazil. UN. 2012. The Future We Want. Rio20 United Nations Conference on Sustainable Development. Rio de Janeiro, Brazil, 20-22 June. A/CONF.216/L.1.

88 Steven Bernstein, 'Rio 20: Sustainable Development in a Time of Multilateral Decline' (2013) 13 Global Environmental Politics 12.

89 See Conference of the Parties, United Nations Framework Convention on Climate Change, Report of the Conference of the Parties on Its Nineteenth Session, held in Warsaw from 11-23 November 2013 - Addendum - Part Two: Action Taken by the Conference of the Parties at Its Nineteenth Session, Dec 2/CP.19, UN Doc FCCC/CP/2013/10/Add.1 (31 January 2014). See also below section 3.3.

90 See UNFCCC, Decision 1/CP.19, Further Advancing the Durban Platform (UN Doc. FCCC/ CP/2013/10/Add.1, 31 January 2014), at paragraph 2.

91 See the Lima Call for Climate Action, Dec. 1/CP.20 (14 December 2014), in COP Report No 20, Addendum, at 2, UN Doc. FCCC/CP/2014/10/Add.1 (2 February 2015) [hereinafter Lima Call for Climate Action]. See also Kenneth Shockley and Idil Boran, 'COP 20 Lima: The ethical dimension of climate negotiations on the way to Paris-Issues, challenges, prospects' (2015) 18(2) Ethics, Policy \& Environment 117.

92 See the Views of Brazil on the Elements of the New Agreement under the Convention Applicable to All Parties' (6 November 2014), available at www4.unfccc.int/submissions/Lists/ OSPSubmissionUpload/73_99_130602104651393682-BRAZIL\%20ADP\%20Elements.pdf. 
and Bolivia, which proposed a compound index for countries' participation in the global emissions budget. ${ }^{93}$

The subsequent adoption of the Paris Agreement was widely hailed as a breakthrough in international climate governance and is likely to be a significant milestone in terms of climate justice. ${ }^{94}$ On the one hand, the agreement provides for differentiated treatment, taking into account the diverse circumstances, capabilities and vulnerabilities of nations, within a convenient degree of flexibility. ${ }^{95}$ On the other hand, it sets out a procedural framework that could, in theory, encourage states to raise their sights in accordance with their existing obligations under the UNFCCC. Thus, their emissions pledges in the collective action could be achieved: maintaining the increase in global average temperature below $2{ }^{\circ} \mathrm{C}$ above pre-industrial levels and pursuing efforts to limit warming to $1.5^{\circ} \mathrm{C}$.

Especially relevant is the Preamble, which notes the importance of 'climate justice', even though the statement which accompanies it states that this concept is important only to 'some'. ${ }^{96}$ Nevertheless, the Preamble mentions that climate change is a common concern of humankind. Especially relevant is the requirement for States:

to respect, promote and consider their respective obligations on human rights, the right to health, the rights of indigenous peoples, local communities, migrants, children, persons with disabilities and people in vulnerable situations and the right to development, as well as gender equality, empowerment of women and intergenerational equity.

It also notes the importance of ensuring the integrity of all ecosystems, including oceans, and the protection of biodiversity. ${ }^{97}$ However, the articles of the Paris Agreement indicate otherwise, especially given the inadequate supporting institutions and insufficient mechanisms..$^{98}$ All the efforts towards social change were relegated to the preamble of the text, diluting its legal force.

Despite some degree of progress, the Paris Agreement, like the Kyoto Protocol, is still a reflection of a perverse status quo in terms of equity, since there is no more favourable treatment of less developed or more vulnerable countries. ${ }^{99}$ Even worse, because of the col-

93 See the Proposal on the Compound Index of Countries Participation in the Global Emission Budget under the Convention Applicable to All Parties' (20 November 2014), available at www4.unfccc .int/submissions/Lists/OSPSubmissionUpload/106_99_130617739555048267-submission\%20bolivia \%20ADP\%20GLOBAL\%20EMISSION\%20BUDGET.

94 See Daniel Bodansky, 'The Paris Climate Change Agreement: a new hope?' (2016) 110 The American Journal of International Law 288; Sandrine Maljean Dubois, 'The Paris Agreement: A New Step in the Gradual Evolution of Differential Treatment in the Climate Regime?' (2016) 25 Review of European Comparative and International Environmental Law 151.

${ }_{95}$ See L. Rajamani, 'Ambition and Differentiation in the 2015 Paris Agreement: Interpretative Possibilities and Underlying Politics’ (2016) 65(2) International and Comparative Law Quarterly, 493.

96 See Rosemary Lyster 'Climate justice, adaptation and the Paris Agreement: a recipe for disasters?' (2017) 26 Environmental Politics 438.

97 See Peter Lawrence 'Soft law in the Paris Climate Agreement: Strength or weakness?' (2017) 26 Review of European Comparative and International Environmental Law 276.

98 See Christina Voigt, 'The Compliance and Implementation Mechanism of the Paris Agreement' (2016) 25(2) Review of European, Comparative and International Environmental Law 161.

99 See Joost Pauwelyn, 'The End of Differential Treatment for Developing Countries? Lessons from the Trade and Climate Change Regimes', (2013) 22(1) Review of European, Comparative and International Environmental Law 29. 
lective progression principle, ${ }^{100}$ this will mean that such countries become subject to more ambitious efforts over time. ${ }^{101}$ In addition, in terms of responsibility, a considerable gap still exists between the nationally determined contributions (NDCs) ${ }^{102}$ of parties and the emissions pathways. ${ }^{103}$ Currently, the NDCs outlining parties' post-2020 action, if fully implemented, would still imply a median warming of $2.6-3.1^{\circ} \mathrm{C}$ by $2100 .{ }^{104}$

Certain critical hopes are expressed in Transforming Our World by 2030: A New Agenda for Global Action, ${ }^{105}$ adopted in 2015 almost in parallel with the Paris Agreement; but no gateways were established between them, beyond the preamble of the Paris Agreement. ${ }^{106}$ The Agenda includes 17 Sustainable Development Goals (SDGs), including requirements to take urgent action to combat climate change and its impact (SDG 13); to build resilient infrastructure (SDG 9); and to make cities and human settlements safe, resilient and sustainable (SDG 11). Meanwhile, terrestrial ecosystems should be protected, restored and sustainably utilized (SDG 15).

However, both the Paris Agreement and the 2030 Agenda are in their earliest stages of implementation, and there is as yet no indication of whether they will meet the challenges posed by anthropogenic climate change. Most of the topics relating to these documents are discussed in this book. Hence, the future direction of climate governance based on justice remains uncertain. There is an urgent need to ensure that institutions for global environmental governance are based on widely shared ethical standards of responsibility and fairness: ${ }^{107}$ solidarity, sustainability, justice, equity and a precautionary approach. ${ }^{108}$

A transition towards a more democratic type of global climate governance is envisaged: ${ }^{109}$ an increased number of non-state actor partnerships in the realm of global climate governance and the growth of public and public-private networks offer the potential for the global climate

100 The notion of progression is based on the FCCC, Decision 1/CP.20, 'Lima Call for Climate Action' (2 February 2015) FCCC/CP/2014/10/Add1, 2, para 10.

101 Notwithstanding that, Article 4(3) expects Parties' successive NDCs to reflect not just progression and 'highest possible ambition', but also their 'common but differentiated responsibilities and respective capabilities, in the light of different national circumstances'.

102 According to Article 4, paragraph 2 of the Paris Agreement, each Party shall prepare, communicate and maintain successive nationally determined contributions which it intends to achieve.

103 United Nations Environment Programme, The Emissions Gap Report 2017. A UN Environment Synthesis Report (United Nations Environment Programme, 2017).

104 See Joeri Rogelj, Michel den Elzen, Niklas Höhne, Taryn Fransen, Hanna Fekete, Harald Winkler, Roberto Schaeffer, Fu Sha, Keywan Riahi and Malte Meinshausen, 'Paris Agreement Climate Proposals Needs a Boost to Keep Warming Well Below $2{ }^{\circ} \mathrm{C}$ ' (2016) 534 Nature 631, 634.

105 See United Nations, Transforming our world: the 2030 Agenda for sustainable development. UN, A/RES/70/1, 2015, available at https://sustainabledevelopment.un.org/ post2015/transformingourworld.

106 See Séan Cleary, 'Reconceptualising transnational governance: making global institutions fit for purpose' (2017) 11 Economics 1.

${ }_{107}$ See Michael Grubb, 'Seeking fair weather? Ethics and the international debate on climate change' (1995) 71 International Affairs 462; and Stephen M. Gardiner, 'Ethics and global climate change' (2004) 114 Ethics 555.

108 See the Declaration of ethical principles in relation to climate change (2017), adopted by UNESCO on 13 November 2017.

109 See Hayley Stevenson and John S. Dryzek, Democratizing global climate governance (Cambridge University Press, 2014). 
arena to develop at a sub-national level. ${ }^{110}$ The concept of climate justice in the Anthropocene requires the promotion of a just transition to a sustainable future free of fossil fuels, which at the same time protects the most vulnerable people and countries from the impact of anthropogenic climate change. There is much work here for constitutionalization to do, given the complexity and the importance of these issues, and the need to promote action beyond institutional actors which are subject to the rules of traditional diplomatic exchange.

110 See Paul Wapner, 'Governance in global civil society' in Oran R. Young (ed), Global Governance: Drawing Insight from Environmental Experience (MIT Press; 1997). 